\title{
JUURNAL.RU
}

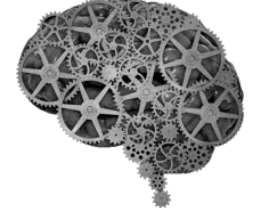

COMPANY GROUP "INTELLEKT"

Кудрявцева М.В., Катаева Н.А. Курского государственного университета

Курск, Россия

doi: 10.18411/lj2016-3-56

\section{Роль упражнений в системе формирования геометрических понятий у младших школьников с интеллектуальными нарушениями}

Проблема формирования понятий давно привлекает внимание психологов и педагогов, в числе которых П. Я. Гальперин, В.В. Давыдов, А.Н. Леонтьев, Н. Г. Салмина, Н.Ф. Талызина, Д.Б.Эльконин и др.

Изучение математических понятий не перестает быть актуальной и в настоящее время. Все математические понятия можно разделить на арифметические и геометрические. Изучение геометрических понятий происходит в разделе математики «Элементы геометрии».

Проведенное нами в 2014-2015 учебном году исследование уровня сформированности понятий элементов геометрии у младших школьников с нарушениями интеллекта, позволило сделать вывод необходимости разработки комплекса упражнений для более успешного формирования геометрических понятий.

Анализ современной психологической литературы указывает на то, что знания это своего рода деятельность, а ее носителем являются именно упражнения.

По данным полученным О.А. Бибиной, можно сделать вывод, что «через систему специальных упражнений можно создать ситуацию, которая способствует осознанию учащимися потребности в геометрических знаниях» [Бибина, 2000]. 
Для наиболее лучшего усвоения геометрических понятий важно сформировать у обучающихся 1-4 классов с нарушениями интеллекта интерес, потребность, которые активизируют познавательную и учебную активность.

Одним из основных условий формирования этой потребности в изучении понятий элементов геометрии является опора на жизненные компетенции школьников с интеллектуальными нарушениями.

Пробуждение интереса к изучению геометрических понятий можно осуществить при помощи рассмотрения моделей как плоскостных (круг, квадрат, прямоугольник, треугольник и т.д.), так и объемных фигур (шар, куб, брус). Не маловажным заданием является рассматривание предметов окружающей среды и нахождение в ней геометрических фигур. Таким образом, происходит опора на наглядно-чувственные образы, которые обеспечивают ознакомление младших школьников с интеллектуальными нарушениями с конкретным геометрическим материалом, соответственно и с геометрическими понятиями.

Для улучшения качества усвоения обучающимися 1-4 классов с нарушениями интеллекта геометрических понятий нами был разработан комплекс занимательных упражнений.

Все упражнения мы распределили по этапам, использованным Г.И. Саранцевым при формировании математических понятий. [Саранцев, 2001]

Начальным этапом является мотивация. Сущность данного этапа заключается «в подчеркивании значимости рассматриваемого понятия, в возбуждении интереса к нему». Приведем примеры:

$\checkmark$ Собери бусы - цель данного упражнения в том, что вспомнить, геометрические фигуры, определить на макетах и правильно нанизать на шнурок.

$\checkmark$ Найди ошибки - цель данного упражнения состоит в том, чтобы находить необходимые геометрические фигуры на рисунке.

Кто больше назовет - цель данного упражнения состоит в том, чтобы найти как можно больше геометрических фигур вокруг себя. 
При выполнении упражнений данного типа позволит не только повысить мотивацию, но и поможет повторить и систематизировать ранее изученные геометрические понятия. Кроме этого у обучающихся 1-4 классов происходит не только вербальное общение с учителем, но и развиваются чертежно-графические умения и навыки.

Следующий этап - это этап, на котором происходит выявление существенных свойств понятия, которые входят в его определение. Этот этап осуществляется при помощи специально подобранных упражнений. Итогом второго этапа должна стать формулировка определения.

$\checkmark$ Прямая линия - решив данное упражнение, мы выясняем, что через одну точку можно провести множество прямых, а через две только одну.

$\checkmark$ Becелье прямые - решив данное упражнение, мы выясняем, что через две точки можно провести только одну прямую.

$\checkmark$ Луч - решив данное задание, мы выясним, что у луча есть начало и не конца.

$\checkmark$ На природе - решив задание, выясним, что у луча есть начало и нет конца.

$\checkmark$ Снежинки - закрепление существенного свойства луча (есть начало).

$\checkmark$ Веселье фигурки - закрепление свойств отрезков.

Выполняя упражнения на данном этапе, школьники являются активными участниками объяснения нового материала. Данный факт является важным особенно при обучении детей с интеллектуальными нарушениями. Именно заинтересованность в получении знаний способствует более осознанному запоминанию и усвоению геометрических понятий.

На следующем этапе усвоения понятий элементов геометрии является усвоение определения понятия. Объектом изучения должно стать каждое существенное свойство, используемое в определении. Осуществляется это также с помощью специальных упражнений направленных на распознавание объектов, принадлежащих этому понятию.

$\checkmark$ Потерямка-закрепление свойств линий. 


\footnotetext{
$\checkmark$ Весельй квадрат - закрепление свойств сторон квадрата.

$\checkmark$ Мы прямоугольники - закрепление свойств сторон прямоугольника.

$\checkmark$ Треугоша-закрепление знаний о треугольниках.

$\checkmark$ Потеряшки- знания углов.
}

Главной особенностью обучающихся с нарушениями интеллекта является неумение формулировать определения. На данном этапе важно, чтобы детям были понятны все слова, которые используются при формировании конкретного понятия. Здесь также можно использовать упражнения с готовыми чертежами, на которых изображены фигуры в различных пространственных расположениях.

Дальнейший этап - это использование понятия в конкретных ситуациях. На этом этапе осуществляется знакомство со свойствами и признаками изучаемого понятия, его определениями. Здесь рекомендуется использовать упражнения, связанные между собой общим понятием.

Очень важно, чтобы при встрече с конкретными геометрическими фигурами обучающиеся с интеллектуальными нарушениями смогли распознать и определить существенные признаки, а соответственно отнести их к конкретному понятию.

Этап систематизации, в которой определяется место изучаемого понятия в системе других понятий.

Заключительный этап - логические операции с понятием, вследствие чего, получаются новые понятия. Этот этап осуществляется посредствам упражнений с использованием операций обобщения, конкретизации, объединения, дополнения и т.д. [Саранцев Г.И. 2001].

Таким образом, можно сделать вывод о том, что именно использование упражнений при формировании понятий элементов геометрии способствует более лучшему их усвоению, развитию пространственного восприятия фигуры, а так же развитию внимания, мышления, памяти и речи. Практическое применение упражнений позволяет эффективно формировать геометрические понятия, повышая при этом общую мотивацию, учить распознавать объекты, 
принадлежащие объему конкретного понятия и выделять его существенные признаки. Изучать понятия в соответствии с межпредметными связями.

\section{Литература:}

1. Бибина О.А. Формирование геометрическийх понятий у школьников с проблемами в интеллектуальном развитии. Дисс.... канд. пед. наук. Саранск. 2000.

2. Бобкова О.В. Формирование геометрических представлений на основе межпредметных связей у младших школьников с нарушением интеллекта (на уроках математики и ручного труда). Дисс....канд.пед.наук. Москва. 2000.

3. Перова М.Н., Эк В.В. Обучение элементам геометрии во вспомогательной школе. Пособие для учителя. 2 - е издание, переработанное. М.: «Просвещение», 1992.

4. Саранцев Г.И. Методология методики обучения математики. Саранск.: «Красный Октябрь», 2001.

5. Талызина Н.Ф. Педагогическая психология: Учеб. для студ. сред. пед. учеб. заведений. - 3 - е изд. стереотип. - М.: Издательский центр «Академия», 1999. 